\title{
Analytical Results of MOX Colemanite Concrete Sample Poured May 4, 2012
}

D.R. Best

A.D. Cozzi

M.M. Reigel

June 2012

Savannah River National Laboratory Savannah River Nuclear Solutions, LLC Aiken, SC 29808

Prepared for the U.S. Department of Energy under contract number DE-AC09-08SR22470. 
SRNL-STI-20120-00344

Revision 0

\section{DISCLAIMER}

This work was prepared under an agreement with and funded by the U.S. Government. Neither the U.S. Government or its employees, nor any of its contractors, subcontractors or their employees, makes any express or implied:

1. warranty or assumes any legal liability for the accuracy, completeness, or for the use or results of such use of any information, product, or process disclosed; or

2. representation that such use or results of such use would not infringe privately owned rights; or

3. endorsement or recommendation of any specifically identified commercial product, process, or service.

Any views and opinions of authors expressed in this work do not necessarily state or reflect those of the United States Government, or its contractors, or subcontractors.

\section{Printed in the United States of America \\ Prepared for U.S. Department of Energy}


Keywords: MOX Colemanite Concrete

Retention: Permanent

\section{Analytical Results of MOX Colemanite Concrete Sample Poured May 4, 2012}

D.R. Best

A.D. Cozzi

M.M. Reigel

June 2012

Savannah River National Laboratory Savannah River Nuclear Solutions, LLC Aiken, SC 29808

Prepared for the U.S. Department of Energy under contract number DE-AC09-08SR22470. 


\section{REVIEWS AND APPROVALS}

AUTHORS:

D.R. Best, Engineering Process Development

Date

A.D. Cozzi, Engineering Process Development

Date

M.M. Reigel, Engineering Process Development

Date

TECHNICAL REVIEW:

B.R. Pickenheim, Engineering Process Development

Date

APPROVAL:

K.M. Fox, Manager

Date

Engineering Process Development

S.L. Marra, Manager

Date

E\&CPT Research Programs 


\section{EXECUTIVE SUMMARY}

The Mixed Oxide Fuel Fabrication Facility (MFFF) will use Colemanite bearing concrete neutron absorber panels credited with attenuating neutron flux in the criticality design analyses. The Savannah River National Laboratory is tasked with measuring the total density, partial hydrogen density, and partial boron density of the colemanite concrete.

Sample 04 May 12/Test/S1-1, S1-2, and S1-3 was received on 5/9/2012 and analyzed. The total density measure by the ASTM method C 642 was $2.00 \mathrm{~g} / \mathrm{cm}^{3}$, within the lower bound of $1.88 \mathrm{~g} / \mathrm{cm}^{3}$. The partial hydrogen density of $6.35 \mathrm{E}-02 \mathrm{~g} / \mathrm{cm}^{3}$ as measured using method ASTM E 1311 met the lower bound of $6.04 \mathrm{E}-02 \mathrm{~g} / \mathrm{cm}^{3}$. The measured partial boron density of $1.88 \mathrm{E}-01 \mathrm{~g} / \mathrm{cm}^{3}$ exceeded the lower bound of $1.65 \mathrm{E}-01 \mathrm{~g} / \mathrm{cm}^{3}$ when the sodium peroxide fusion dissolution method was used in place of the prescribed ASTM C 1301 method. 


\section{TABLE OF CONTENTS}

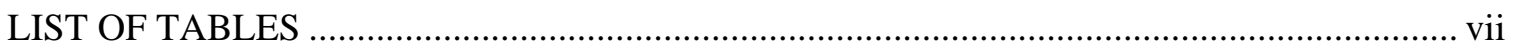

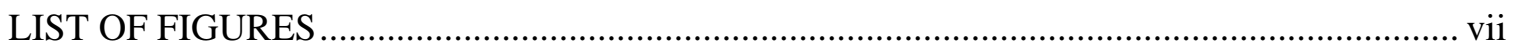

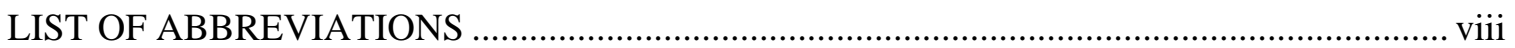

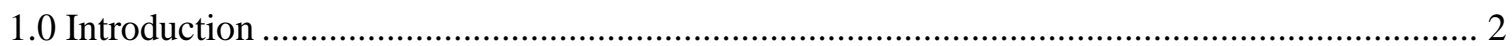

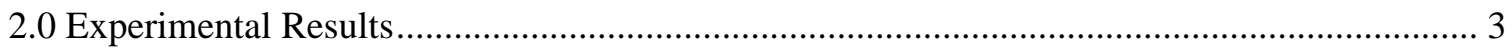

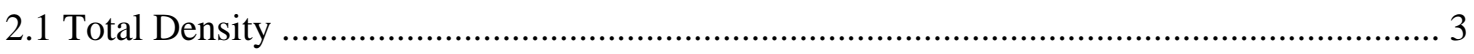

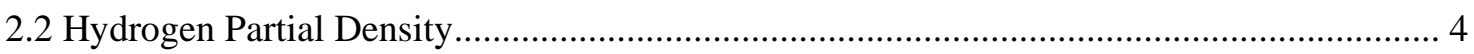

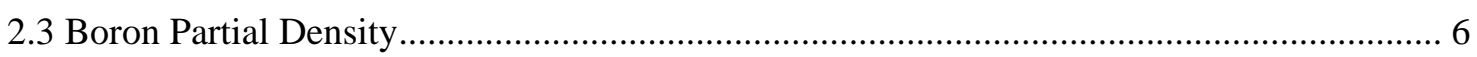

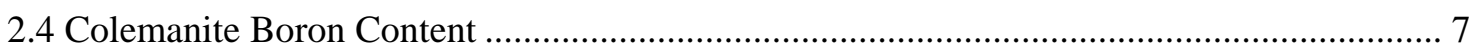

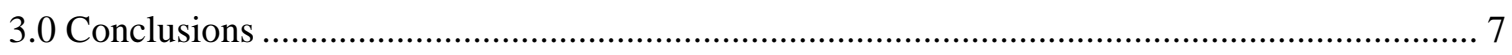

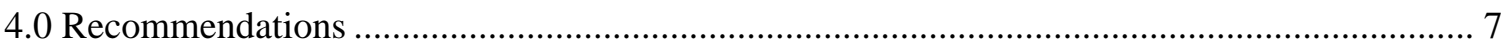

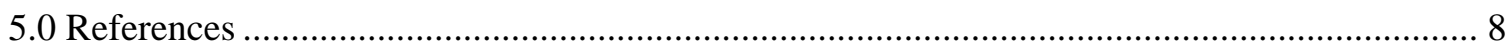




\section{LIST OF TABLES}

Table 1 Acceptable Material Neutron Absorber Characteristics ..................................................... 2

Table 2 Mix Design and Density Ranges for Colemanite Concrete............................................... 2

Table 3 Mix Design used to Prepare the May 4, 2012 Sample. ..................................................... 2

Table 4 Mass Measurements of Subsamples After Each Treatment. ............................................. 4

Table 5 Calculated Results of Equations 1-7 for the Colemanite Concrete. .................................. 4

Table 6 Mass change Over Temperature Ranges for S1-1 and S1-2_........................................ 5

Table 7 Boron Results of Colemanite Concrete Analyzed using ASTM C 1301........................... 6

Table 8 Boron Results of Colemanite Concrete Analyzed using L29-ITS-0040_......................... 6

Table 9 Boron Results of Colemanite Analyzed using L29-ITS-0040 ......................................... 7

Table 10 Lower Bounds and Measured Values for the Total Density, Hydrogen Partial Density, and Boron Partial Density for the Colemanite Concrete Sample, 04 May 2012..................... 7

\section{LIST OF FIGURES}

Figure 1 Colemanite Concrete Samples Poured May 4, 2012 ......................................................... 3

Figure 2 Portions of S1-1 and S1-2 Used for density Determination........................................... 3

Figure 3 TGA Curve Showing Mass Loss of S1-1 and S1-2 Heated at $5{ }^{\circ} \mathrm{C} / \mathrm{min}$ Under Flowing

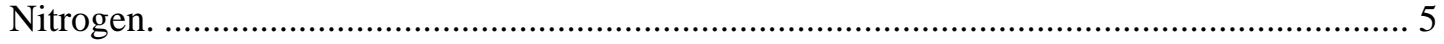




\section{LIST OF ABBREVIATIONS}

$\begin{array}{ll}\text { DSC } & \text { Differential Scanning Calorimetry } \\ \text { ICP } & \text { Inductively Coupled Plasma } \\ \text { MFFF } & \text { Mixed Oxide Fuel Fabrication Facility } \\ \text { OES } & \text { Optical Emission Spectroscopy } \\ \text { PSAL } & \text { Process Science Analytical Laboratory } \\ \text { SRNL } & \text { Savannah River National Laboratory } \\ \text { TGA } & \text { Thermal Gravimetric Analysis }\end{array}$




\subsection{Introduction}

The Mixed Oxide Fuel Fabrication Facility (MFFF) will use Colemanite bearing concrete neutron absorber panels credited with attenuating neutron flux in the criticality design analyses ${ }^{1}$. Table 1 is an excerpt from Table 2.1.2.3 in Reference 1.

Table 1 Acceptable Material Neutron Absorber Characteristics

\begin{tabular}{|c|c|c|c|}
\hline Material Type & $\begin{array}{l}\text { Total Density Lower } \\
\text { Bound }\left(\mathrm{g} / \mathrm{cm}^{3}\right)\end{array}$ & $\begin{array}{c}\text { Hydrogen Partial Density } \\
\text { Lower Bound }\left(\mathrm{g} / \mathrm{cm}^{3}\right)\end{array}$ & $\begin{array}{l}\text { Boron Partial Density } \\
\text { Lower Bound }\left(\mathrm{g} / \mathrm{cm}^{3}\right)\end{array}$ \\
\hline $\begin{array}{l}\text { Borated Concrete } \\
\text { (Colemanite) }\end{array}$ & 1.88 & 6.04E-02 & 1.65E-01 \\
\hline
\end{tabular}

Table 2 is the design mix per cubic yard from Reference 1. Included in the table are densities of the individual components. The projected density was calculated for each water to cement ratio to determine a range of acceptable concrete densities.

Table 2 Mix Design and Density Ranges for Colemanite Concrete.

\begin{tabular}{|c|c|c|c||}
\hline Mix Component & $\begin{array}{c}\text { Mass } \\
(\mathbf{l b})\end{array}$ & $\begin{array}{c}\text { Density } \\
\left(\mathbf{g} / \mathbf{c m}^{\mathbf{3}}\right)\end{array}$ & $\begin{array}{c}\text { Mix Density } \\
\left(\mathbf{g} / \mathbf{c m}^{\mathbf{3}}\right)\end{array}$ \\
\hline Cement & 700 & 3.11 & -- \\
\hline Colemanite Aggregate & 2175 & 2.42 & -- \\
\hline Water to Cement & & & \\
\hline 0.45 & 315 & 1 & 2.22 \\
\hline $0.8^{2}$ & 560 & 1 & 2.04 \\
\hline
\end{tabular}

The Savannah River National Laboratory/E\&CPT Research Programs/Engineering Process Development Group is tasked with measuring the properties of the colemanite concrete identified in Table $1^{3}$. Table 3 is the actual mix prepared for the sample May 4, 2012, see Appendix A.

Table 3 Mix Design used to Prepare the May 4, 2012 Sample.

\begin{tabular}{|c|c|}
\hline Mix Component & $\begin{array}{c}\text { Mass } \\
\text { (lb) }\end{array}$ \\
\hline Cement & 456 \\
\hline Colemanite Aggregate & 1422 \\
\hline Water & 421 \\
\hline
\end{tabular}

These values represent a calculated density of $1.99 \mathrm{~g} / \mathrm{cm}^{3}$ and a water to cement ratio of 0.92 . 


\subsection{Experimental Results}

Sample 04 May 12/Test/S1-1, S1-2 and S1-3 was received on May 9, 2012. The sample identifications were inconsistent with those provided from MOX and were corrected upon receipt to reflect the as received labels, Appendix B. Figure 1 is a photograph of the samples as received. The sample was divided into three subsamples by the customer to provide sufficient material for the requested analysis.

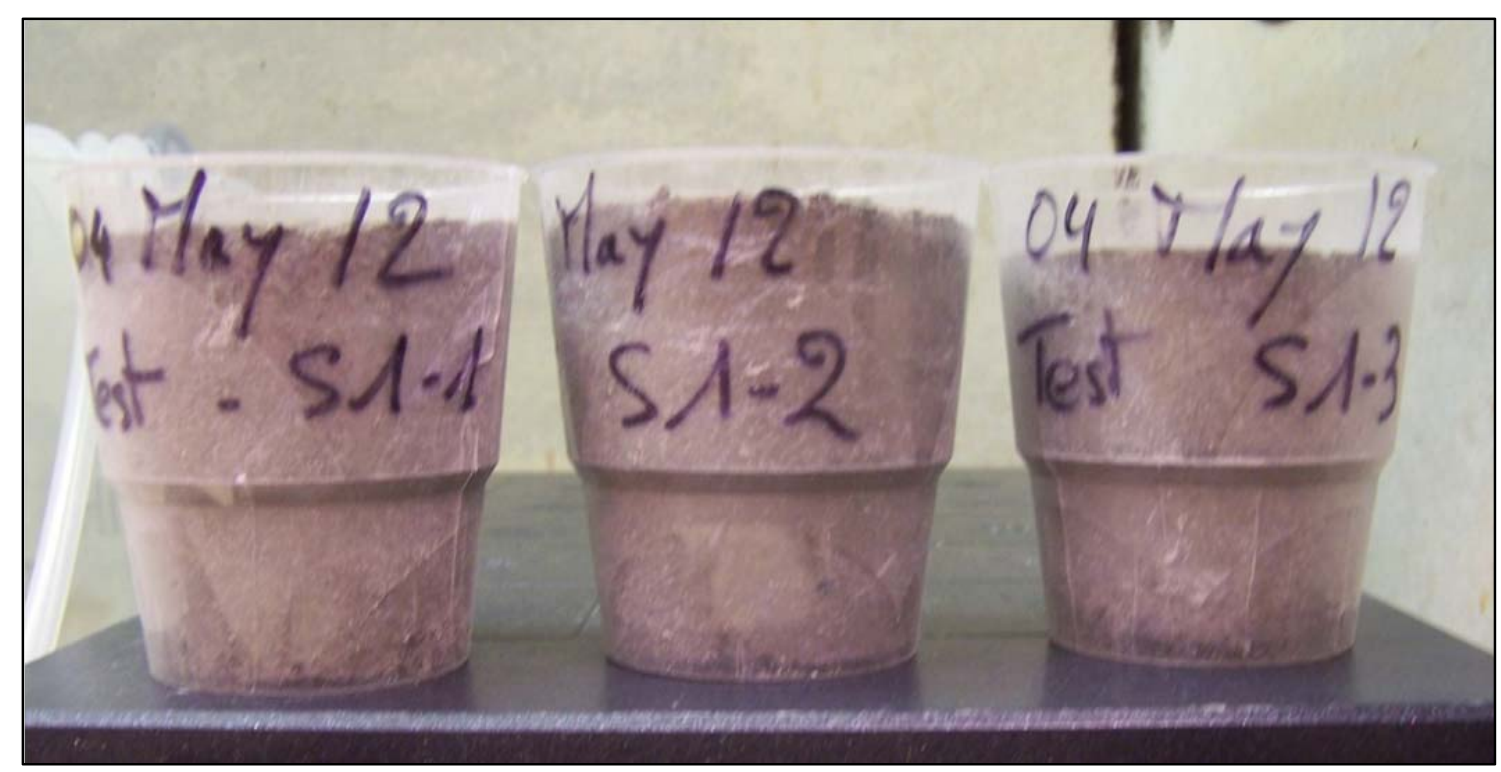

Figure 1 Colemanite Concrete Samples Poured May 4, 2012.

\subsection{Total Density}

The total density of the sample was determined by the ASTM method for density in hardened concrete ${ }^{4}$. Subsamples S1-1 and S1-2 were crushed and placed in labeled bags. A portion of each of these samples was used for the density determination, Figure 2. Subsample S1-3 was reserved if reanalysis was needed.
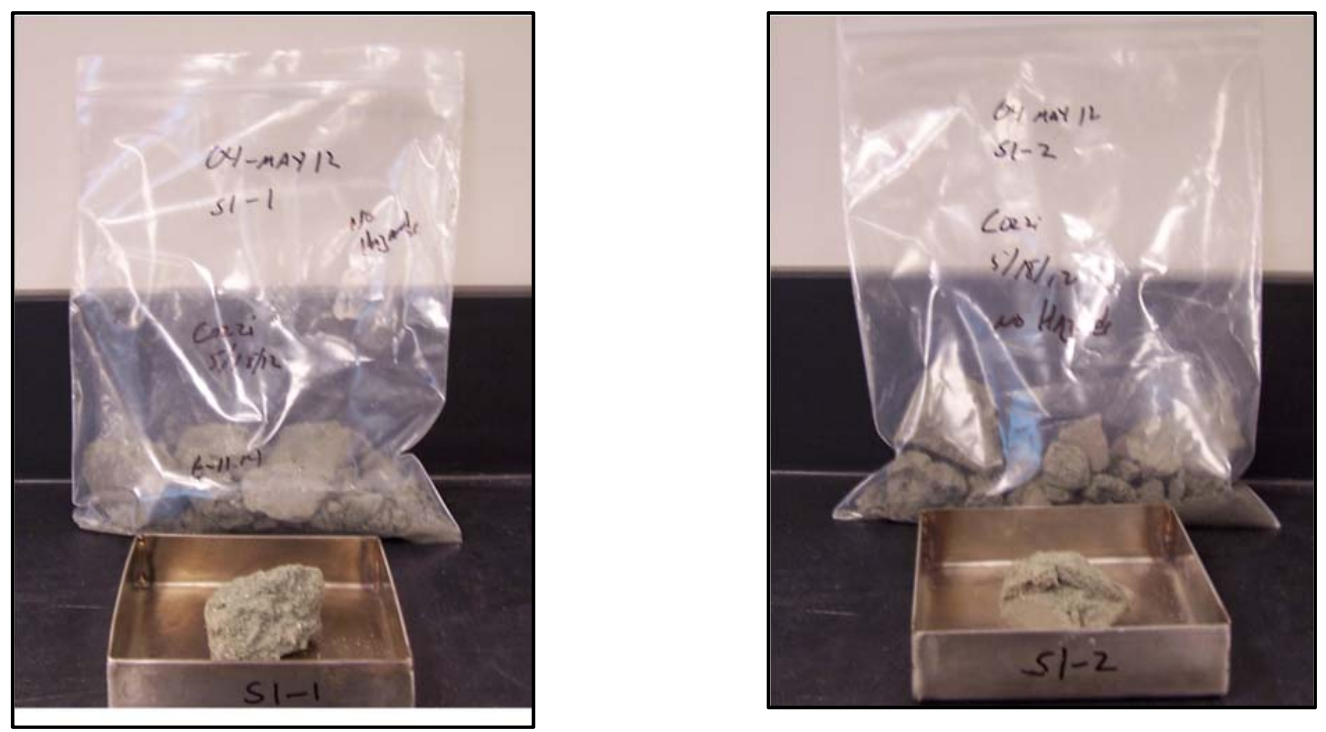

Figure 2 Portions of S1-1 and S1-2 Used for density Determination. 
The ASTM method was followed with the exception of sample size. Section 4.1 of the procedure specifies a sample size of approximately 800 grams. As each subsample weighed between 300-400 grams, a reduced sample size was used. Mass measurements were taken after each treatment with the masses being designated A through D, where;

A = mass of oven-dried sample in air, g

$\mathrm{B}=$ mass of surface-dry sample in air after immersion, $\mathrm{g}$

$\mathrm{C}=$ mass of surface-dry sample in air after immersion and boiling, $\mathrm{g}$

$\mathrm{D}=$ apparent mass of sample in water after immersion and boiling, g, Table 4 .

Table 4 Mass Measurements of Subsamples After Each Treatment.

\begin{tabular}{|c|c|c|c|c|}
\hline \hline Subsample & A (g) & B (g) & C (g) & D (g) \\
\hline Treatment & dry & saturated & boil/saturated & suspended \\
\hline Date & 21-May & 23-May & 24-May & 24-May \\
\hline S1-1 & 38.991 & 46.506 & 46.703 & 23.5536 \\
\hline S1-2 & 31.425 & 38.019 & 38.177 & 18.9882 \\
\hline
\end{tabular}

Using the calculations in the ASTM method, the following properties were measured;

Absorption after immersion, $\%=[(\mathrm{B}-\mathrm{A}) / \mathrm{A}] \mathrm{X} 100$,

Absorption after immersion and boiling, $\%=[(\mathrm{C}-\mathrm{A}) / \mathrm{A}] \mathrm{X} 100$,

Bulk density, dry $=[\mathrm{A} /(\mathrm{C}-\mathrm{D})] \mathrm{X}$ density of water $\left(\sim 1 \mathrm{~g} / \mathrm{cm}^{3}\right)$,

Bulk density after immersion $=\left[B /(C-D) X\right.$ density of water $\left(\sim 1 \mathrm{~g} / \mathrm{cm}^{3}\right)$,

Bulk density after immersion and boiling $=\left[C /(C-D) X\right.$ density of water $\left(\sim 1 \mathrm{~g} / \mathrm{cm}^{3}\right)$,

Apparent density $=\left[\mathrm{A} /(\mathrm{A}-\mathrm{D}) \mathrm{X}\right.$ density of water $\left(\sim 1 \mathrm{~g} / \mathrm{cm}^{3}\right)$,

Volume of permeable pore space $=(C-A) /(C-D) X 100$.

The results of the calculations performed with equations 1-7 are tabulated and averaged in Table 5

Table 5 Calculated Results of Equations 1-7 for the Colemanite Concrete.

\begin{tabular}{|c|c|c|c|c|c|c|c|}
\hline $\begin{array}{c}\text { Sample } \\
\text { ID }\end{array}$ & $\begin{array}{l}\text { Absorption } \\
\text { Eq (1) (\%) }\end{array}$ & $\begin{array}{l}\text { Absorption } \\
\text { Eq (2) (\%) }\end{array}$ & $\begin{array}{c}\text { Bulk } \\
\text { Density } \\
\text { Eq (3) } \\
\left(\mathrm{g} / \mathrm{cm}^{3}\right)\end{array}$ & $\begin{array}{c}\text { Bulk } \\
\text { Density } \\
\text { Eq (4) } \\
\left(\mathbf{g} / \mathbf{c m}^{3}\right)\end{array}$ & $\begin{array}{c}\text { Bulk } \\
\text { Density } \\
\text { Eq (5) } \\
\left(\mathbf{g} / \mathbf{c m}^{3}\right)\end{array}$ & $\begin{array}{c}\text { Apparent } \\
\text { Density } \\
\text { Eq (6) } \\
\left(\mathrm{g} / \mathrm{cm}^{3}\right)\end{array}$ & $\begin{array}{c}\text { Permeable } \\
\text { void \% } \\
\text { Eq (7) }\end{array}$ \\
\hline S1-1 & 19.3 & 19.8 & 1.68 & 2.01 & 2.02 & 2.53 & 33.31 \\
\hline S1-2 & 21.0 & 21.5 & 1.64 & 1.98 & 1.99 & 2.53 & 35.19 \\
\hline Average & 20.1 & 20.6 & 1.66 & 2.00 & 2.00 & 2.53 & 34.25 \\
\hline
\end{tabular}

Equations (4) and (5) are the most appropriate to represent the density of the Colemanite concrete as the concrete is saturated with water during placement.

\subsection{Hydrogen Partial Density}

The hydrogen partial density of the colemanite concrete was determined using the ASTM method for determining volatile content using thermogravimetric analysis ${ }^{5}$. The ASTM E 1131-08 defines highly volatile matter as components that will volatilize $<200^{\circ} \mathrm{C}$ and medium volatile matter as components that will degrade or volatilize in the range $200-750{ }^{\circ} \mathrm{C}$. In an evaluation of the thermal decomposition of colemanite, Waclawska et al, determined that the release of water from colemanite was complete at $600{ }^{\circ} \mathrm{C}$ and that melting and crystallization of a calcium borate phase occurred above $650{ }^{\circ} \mathrm{C}^{6}$. A Netzsch STA 409 Luxx, which couples Differential Scanning Calorimetry (DSC) with Thermal Gravimetric Analysis (TGA), was used for TGA of the 
colemanite concrete samples. After loading the sample, the chamber was purged with nitrogen at $60 \mathrm{~mL} / \mathrm{min}$ prior to heating. Samples from S1-1 and S1-2 were heated at $5{ }^{\circ} \mathrm{C} / \mathrm{min}$ up to $650{ }^{\circ} \mathrm{C}$ in a flowing nitrogen atmosphere of $60 \mathrm{~mL} / \mathrm{min}$, Figure 3 . Table 6 is the mass change for the four samples.

Table 6 Mass change Over Temperature Ranges for S1-1 and S1-2.

\begin{tabular}{|c|c|c|c|}
\hline Sample ID & $\begin{array}{c}\text { Mass Change } \\
25-175^{\circ} \mathrm{C}\end{array}$ & $\begin{array}{l}\text { Mass Change } \\
350-650^{\circ} \mathrm{C}\end{array}$ & $\begin{array}{c}\text { Total Mass } \\
\text { Change }\end{array}$ \\
\hline S1-1A & $15.17 \%$ & $9.83 \%$ & $25.86 \%$ \\
\hline S1-1B & $17.25 \%$ & $12.28 \%$ & $30.74 \%$ \\
\hline S1-2A & $16.99 \%$ & $9.43 \%$ & $27.44 \%$ \\
\hline S1-2B & $17.62 \%$ & $10.36 \%$ & $29.36 \%$ \\
\hline Average & $16.76 \%$ & $10.48 \%$ & $28.35 \%$ \\
\hline
\end{tabular}

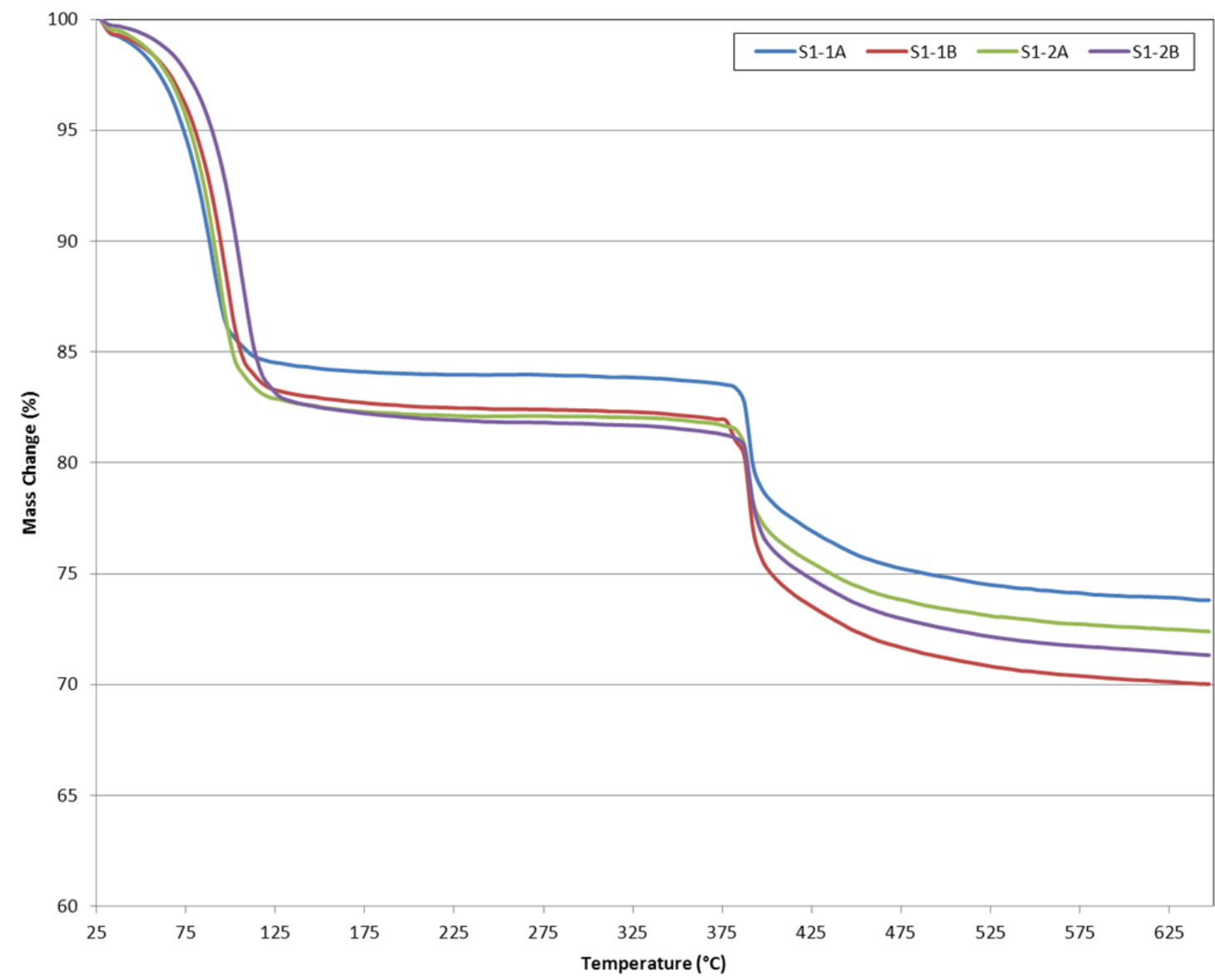

Figure 3 TGA Curve Showing Mass Loss of S1-1 and S1-2 Heated at $5{ }^{\circ} \mathrm{C} / \mathrm{min}$ Under Flowing Nitrogen.

Attributing the weight loss in Table 6 to water results in 28.35 wt\% water, and using a measured colemanite concrete density of $2.00 \mathrm{~g} / \mathrm{cm}^{3}$, the partial hydrogen density is calculated to be $6.35 \mathrm{E}-02 \mathrm{~g} / \mathrm{cm}^{3}$. 


\subsection{Boron Partial Density}

Approximately 20 grams of Sample S1-2 was crushed in an Angstrom TE250 laboratory ring pulverizer with tungsten carbide components to ensure homogeneity of the sample. The sample was then digested in triplicate using the ASTM method for trace metals analysis in limestone ${ }^{7}$. Three aliquots of sample (1.0035 g, $1.0065 \mathrm{~g}, 1.0085 \mathrm{~g})$ were weighed in separate beakers and then $10 \mathrm{ml}$ of $\mathrm{HCl}$ and $4 \mathrm{ml} \mathrm{HNO}_{3}$ were added. The acid mixture was heated at $85{ }^{\circ} \mathrm{C}$ for 30 minutes on a hotplate, with the sample covered with a watch glass. The sample was then diluted up to a final volume of $100 \mathrm{ml}$ with deionized water. The samples were analyzed on the Agilent 730 Inductively Coupled Plasma-Optical Emission Spectroscopy (ICP-OES). Boron was calibrated using a High Purity NIST traceable standard (Lot 1204016). An internal standard (Yttrium) was used to compensate for matrix effects. A High Purity NIST traceable mixed aqueous standard (expected boron value - $20 \mathrm{mg} / \mathrm{L}$, Appendix C: Certificate of Analysis) was run to verify the calibration. The dissolution method prescribed in the ASTM method did not result in complete dissolution of the samples. Undissolved solids remained in the container. Table 7 is the analytical results of the dissolution of colemanite concrete using the prescribed ASTM method.

Table 7 Boron Results of Colemanite Concrete Analyzed using ASTM C 1301.

\begin{tabular}{|c|c|}
\hline Sample ID & Boron Content \\
\hline Custom & $20.01 \mathrm{mg} / \mathrm{L}$ \\
\hline S1-2 (A) & $6.25 \mathrm{wt} \%$ \\
\hline S1-2 (B) & $6.98 \mathrm{wt} \%$ \\
\hline S1-2 (C) & $7.03 \mathrm{wt} \%$ \\
\hline
\end{tabular}

The aqua regia sample digestions did not provide a complete dissolution, so the sample was also digested using a fusion technique $\left(\mathrm{Na}_{2} \mathrm{O}_{2} / \mathrm{NaOH} / \mathrm{HCl}\right)$ - SRNL Technical Reference L29-ITS0040. The sodium peroxide is used to oxidize the sample to increase the solubility of the sample in acid. The method allows for complete dissolution of materials such as glass, cement, and soils for elemental analyses by ICP or atomic absorption.

The crushed sample was digested in triplicate by adding $0.1524 \mathrm{~g}, 0.1515 \mathrm{~g}$ and $0.1505 \mathrm{~g}$ to platinum crucibles. $1.5 \mathrm{~g}$ of sodium peroxide and $1.0 \mathrm{~g}$ of sodium hydroxide were fused with the sample for 15 minutes at $\sim 650{ }^{\circ} \mathrm{C}$ in a muffle furnace. The sample flux was cooled and then digested with $25 \mathrm{ml}$ of hydrochloric acid and deionized water. The sample was diluted to a final volume of $250 \mathrm{ml}$ with deionized water. The dissolution resulted in a clear liquid with all the colemanite concrete digested.

The samples were analyzed on the Agilent 730 ICP-OES. Boron was calibrated using a High Purity NIST traceable standard (Lot 1204016) in a matrix matched solution. A glass standard with a known amount of boron (2.41 wt\%) was also digested and analyzed to verify the calibration. Table 8 is the boron results from the same sample lot in Table 7 using a more aggressive dissolution method.

Table 8 Boron Results of Colemanite Concrete Analyzed using L29-ITS-0040.

\begin{tabular}{|c|c|}
\hline Sample ID & Boron Content \\
\hline Glass Std & $2.47 \mathrm{wt} \%$ \\
\hline S1-2 (A) & $9.31 \mathrm{wt} \%$ \\
\hline S1-2 (B) & $9.46 \mathrm{wt} \%$ \\
\hline S1-2 (C) & $9.55 \mathrm{wt} \%$ \\
\hline Average & $9.44 \mathrm{wt} \%$ \\
\hline
\end{tabular}


The results show that the $\mathrm{Na}_{2} \mathrm{O}_{2} / \mathrm{NaOH} / \mathrm{HCl}$ fusion digestion is a more thorough technique in dissolving the colemanite concrete and thus determining the boron content.

Attributing the weight loss in Table 6 to water results in $28.35 \mathrm{wt} \%$ water, and using a measured colemanite concrete density of $2.00 \mathrm{~g} / \mathrm{cm}^{3}$, the partial boron density is calculated to be $1.88 \mathrm{E}-01 \mathrm{~g} / \mathrm{cm}^{3}$.

\subsection{Colemanite Boron Content}

A one kilogram sample of colemanite aggregate was received into the PSAL on June 7, 2012. The entire sample was distributed evenly in a shallow pan. Ten samples of approximately $10 \mathrm{~g}$ each were collected from various area of the pan. The samples were combined and size reduced in an Angstrom TE250 laboratory ring pulverizer with tungsten carbide components. Three subsamples of the size reduced colemanite were digested using the fusion digestion technique described in Section 2.3 and analyzed for boron using an Agilent 730 ICP-OES. Table 9 is the results of the boron analysis of the colemanite aggregate.

Table 9 Boron Results of Colemanite Analyzed using L29-ITS-0040.

\begin{tabular}{||c|c|}
\hline Sample ID & Boron Content \\
\hline Glass Std & $2.52 \mathrm{wt} \%$ \\
\hline Colemanite AREVA (A) & $12.41 \mathrm{wt} \%$ \\
\hline Colemanite AREVA (B) & $12.84 \mathrm{wt} \%$ \\
\hline Colemanite AREVA (C) & $12.67 \mathrm{wt} \%$ \\
\hline Average & $12.64 \mathrm{wt} \%$ \\
\hline
\end{tabular}

Lab notebook SRNL-NB-2012-00063 was used for this activity.

\subsection{Conclusions}

The limits and measured values for the total density, hydrogen partial density, and boron partial density are presented in Table 10 . The total density, the hydrogen partial density, and the boron partial density exceeded the lower bounds specified in Reference 1.

Table 10 Lower Bounds and Measured Values for the Total Density, Hydrogen Partial Density, and Boron Partial Density for the Colemanite Concrete Sample, 04 May 2012.

\begin{tabular}{|c|c|c|c|c|c|c|}
\hline \multirow[t]{2}{*}{ Material Type } & \multicolumn{2}{|c|}{$\begin{array}{c}\text { Total Density Lower } \\
\text { Bound }\left(\mathrm{g} / \mathrm{cm}^{3}\right)\end{array}$} & \multicolumn{2}{|c|}{$\begin{array}{c}\text { Hydrogen Partial Density } \\
\text { Lower Bound }\left(\mathrm{g} / \mathrm{cm}^{3}\right)\end{array}$} & \multicolumn{2}{|c|}{$\begin{array}{l}\text { Boron Partial Density } \\
\text { Lower Bound }\left(\mathrm{g} / \mathrm{cm}^{3}\right)\end{array}$} \\
\hline & Limit & Measured & Limit & Measured & Limit & Measured \\
\hline $\begin{array}{l}\text { Borated Concrete } \\
\text { (Colemanite) }\end{array}$ & 1.88 & 2.00 & 6.04E-02 & 6.35E-02 & $1.65 \mathrm{E}-01$ & $1.88 \mathrm{E}-01$ \\
\hline
\end{tabular}

\subsection{Recommendations}

The ASTM C1301-95 procedure using aqua regia is for the analysis of limestone and should not be considered a viable method for colemanite concrete. SRNL recommends using the boron results from the $\mathrm{Na}_{2} \mathrm{O}_{2} / \mathrm{NaOH} / \mathrm{HCl}$ fusion digestion as the true result in sample 04 May 12/Test/S1-2. 


\subsection{References}

1 Wead, R., "Radiation Shielding and Fixed Neutron Absorber Panel Material and Inspection Requirements," DCS01-ZMJ-DS-SPE-M-19109-2, Revision 2. (2007).

2 "Clarification of Colemanite Concrete Requirement," ECR-016383, Revision 1, 2/29/2012.

3 " Equipment Calibration Services / Material Testing," WTA-040-8b, Section 9 (q), 4/13/2012.

4 " Standard Test Method for Density, Absorption, and Voids in Hardened Concrete," ASTM C 642-06.

5 "Standard Test Method for Compositional Analysis by Thermogravimetry," ASTM E 1131-08.

${ }^{6}$ Waclawska, I, Stoch, L, Paulik, J., and Paulik, F., "Thermal Decomposition of Colemanite," Thermochimica Acta, pp. 307-318, [126] (1988).

7 "Major and Trace Elements in Limestone and Lime by Inductively Coupled Plasma-Atomic Emission Spectroscopy (ICP) and Atomic Absorption (AA)," ASTM C 1301-95 (Reapproved 2009). 
SRNL-STI-20120-00344

Revision 0

Appendix A. Correspondence Noting Mix Ratios 
SRNL-STI-20120-00344

Revision 0

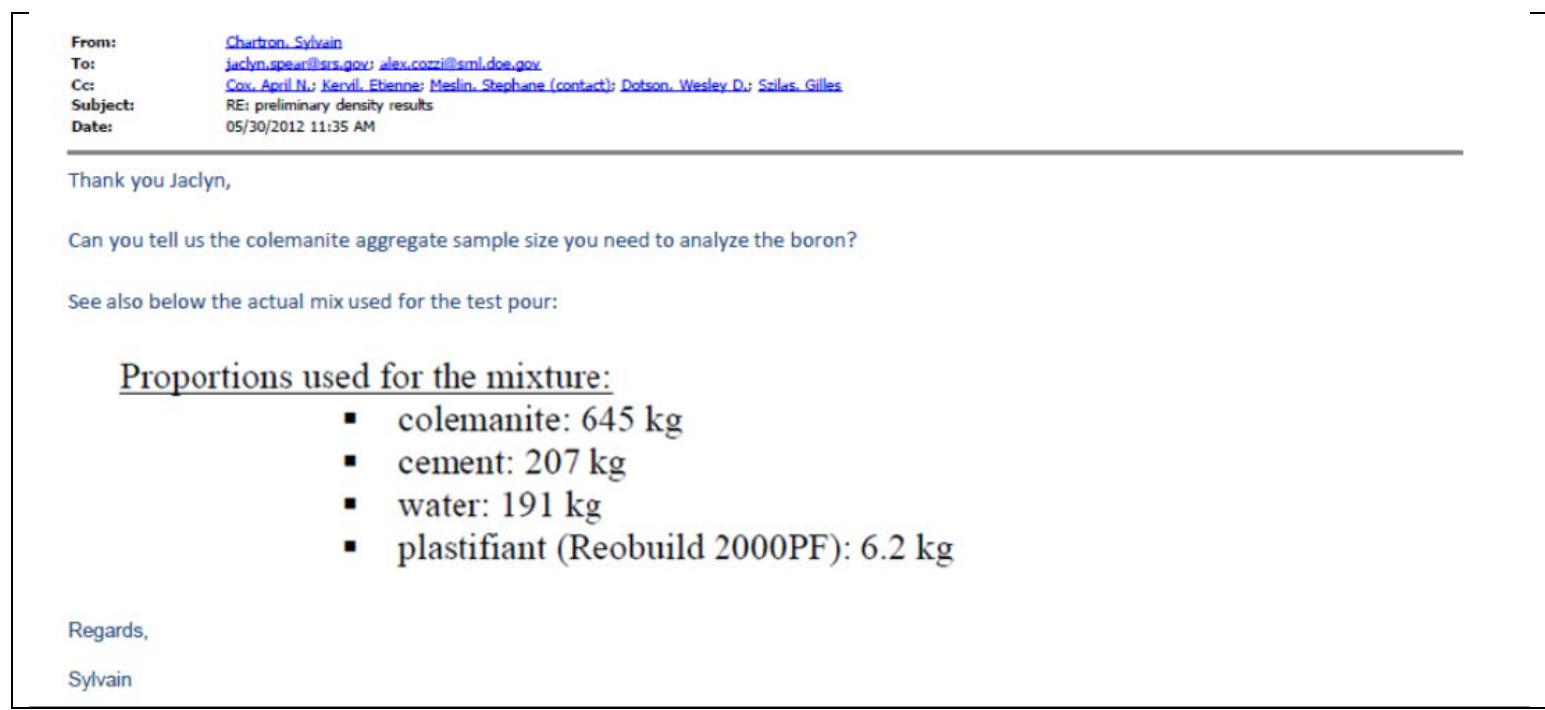


SRNL-STI-20120-00344

Revision 0

Appendix B. Correspondence Clarifying Sample Labels 


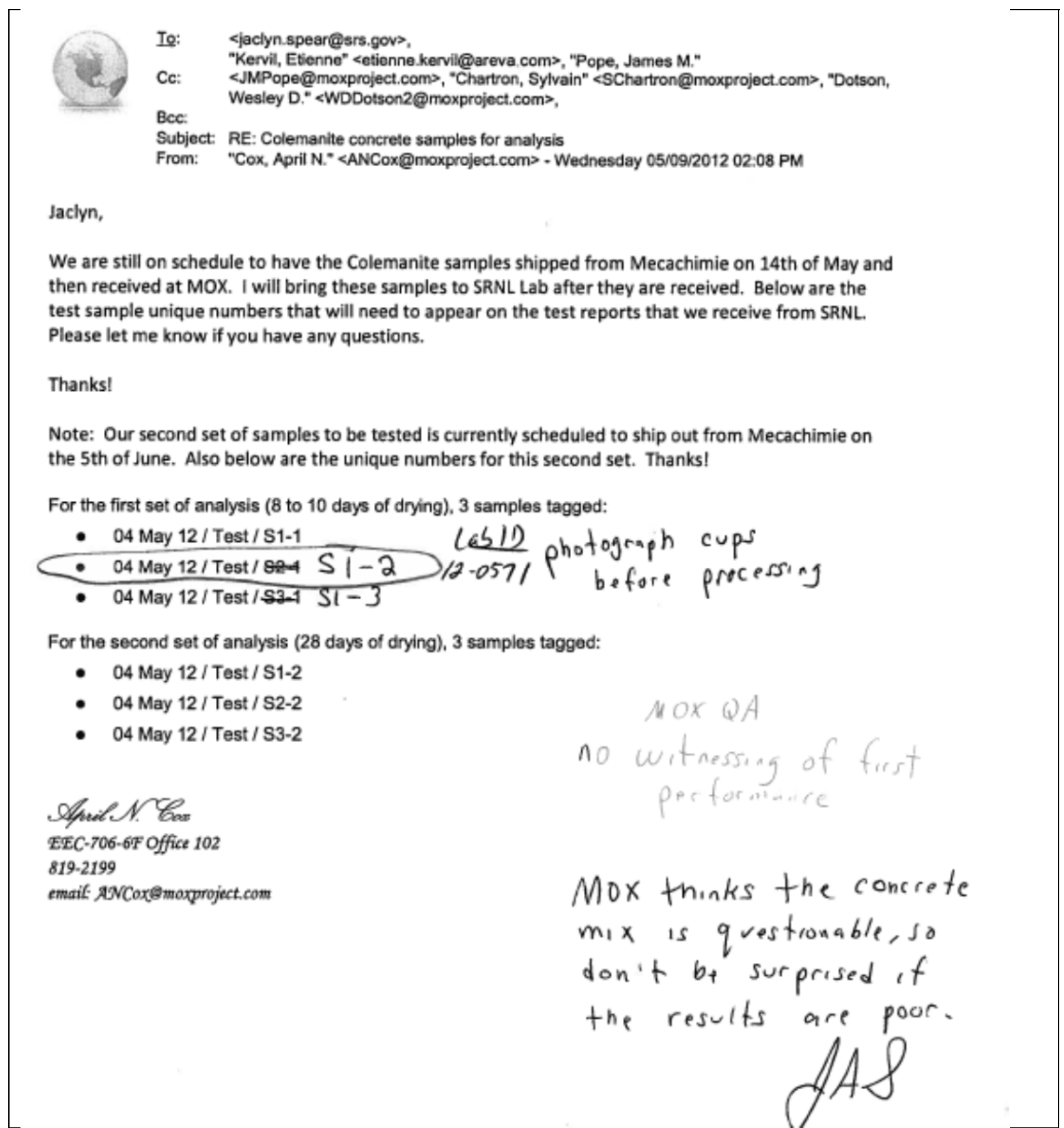


SRNL-STI-20120-00344

Revision 0

Appendix C. Boron Certificate of Analysis 


\title{
4 HICH-PUEITY \\ memahighanoyatandardscom
}

\section{Certifícate of Analpsis}

\section{Product Description:}

$\begin{array}{llll}\text { Name: } & \text { Boron } & \text { Source Material: } & \text { Boric Acid } \\ \text { Part Number: } & 10007-4 & \text { Material Purity: } & 99.999 \% \\ \text { Lot Number: } & 1204016 & \text { Matrix: } & \mathrm{H}_{2} \mathrm{O}\end{array}$

\section{Certified Value:}

$1000 \mu \mathrm{g} / \mathrm{mL} \pm 3 \mu \mathrm{g} / \mathrm{mL}$

The Certified value is based on gravimetric and volumetric preparation, and confirmed against SRM 3107 (lot number 070514 ) by inductively coupled plasma optical emission spectrometry (ICP-OES) using an internal laboratory-developed method. The uncertainty in the certified value is calculated for a $95 \%$ confidence interval and coverage factor $k$ is about 2 .

Density:

$$
1.000 \mathrm{~g} / \mathrm{mL} \pm 0.002 \mathrm{~g} / \mathrm{mL} @ 22.8^{\circ} \mathrm{C}
$$

\section{Uncertified Values:}

\section{Titration Value: $\quad 994.97 \mu \mathrm{g} / \mathrm{mL}$}

Trace Metal Impurity Scan: The data reported are based upon a scan of this specific lot at $1000 \mu \mathrm{g} / \mathrm{mL}$ via ICP analysis. The values are reported in $\mu \mathrm{g} / \mathrm{L}$.

\begin{tabular}{|c|c|c|c|c|c|c|c|c|c|c|c|c|c|}
\hline $\mathrm{Ag}$ & 0.02 & $\mathrm{Cu}$ & $<$ & 0.1 & $\mathbf{L i}$ & $<$ & 1 & $\mathbf{R b}$ & $<$ & $0.0 ?$ & Th & $<$ & 0.02 \\
\hline $\mathrm{Al}$ & 0.1 & Dy & $<$ & 0.02 & $\mathrm{Lu}$ & $<$ & 0.02 & Re & $<$ & 0.02 & $\mathrm{~T}$ & $<$ & 0.02 \\
\hline As & 0.05 & Er & $<$ & 0.02 & $\mathrm{Mg}$ & $<$ & 0.5 & $\mathbf{R h}$ & $<$ & 0.02 & $\pi$ & $<$ & 0.02 \\
\hline Au & 0.02 & Eu & $<$ & 0.02 & $\mathrm{Mn}$ & $<$ & 0.5 & $\mathbf{R u}$ & $<$ & 0.02 & $\mathrm{Tm}$ & $<$ & 0.02 \\
\hline B & $\mathrm{M}$ & $\mathrm{Fe}$ & $<$ & 5 & Mo & $<$ & 0.02 & Sb & $<$ & 0.02 & $\mathbf{U}$ & $<$ & 0.1 \\
\hline Ba & 0.1 & $\mathrm{Ga}$ & $<$ & 0.02 & $\mathrm{Na}$ & $<$ & 10 & $\mathrm{Sc}$ & $<$ & 0.02 & v & $<$ & 0.05 \\
\hline $\mathrm{Be}$ & 0.02 & Gd & $<$ & 0.02 & $\mathrm{Nb}$ & $<$ & 0.02 & $\mathrm{Se}$ & $<$ & 0.1 & w & $<$ & 0.02 \\
\hline $\mathrm{Bi}$ & 0.02 & $\mathrm{Ge}$ & $<$ & 0.02 & Nd & $<$ & 0.02 & $\mathbf{S i}$ & $<$ & 5 & $\mathrm{Y}$ & $<$ & 0.02 \\
\hline $\mathrm{Ca}$ & 5 & $\mathrm{Hf}$ & $<$ & 0.02 & $\mathrm{Ni}$ & $<$ & 0.02 & Sm & $<$ & 0.02 & $\mathrm{Yb}$ & $<$ & 0.02 \\
\hline $\mathrm{Cd}$ & 0.02 & Ho & $<$ & 0.02 & Os & $<$ & 0.02 & $\mathrm{Sn}$ & $<$ & 1 & $\mathrm{Zn}$ & $<$ & 0.1 \\
\hline $\mathrm{Ce}$ & 0.02 & In & $<$ & 0.02 & $\mathrm{~Pb}$ & $<$ & 0.05 & $\mathrm{Sr}$ & $<$ & 0.02 & $\mathrm{Zr}$ & $<$ & 0.02 \\
\hline Co & 0.05 & Ir & $<$ & 0.02 & Pd & $<$ & 0.02 & $\mathrm{Ta}$ & $<$ & 0.02 & & & \\
\hline $\mathrm{Cr}$ & 0.1 & K & $<$ & 1 & $\mathrm{Pt}$ & $<$ & 0.02 & $\mathrm{~Tb}$ & $<$ & 0.02 & & & \\
\hline $\mathrm{Cs}$ & 0.02 & La & $<$ & 0.02 & $\mathrm{Pt}$ & $<$ & 0.02 & $\mathrm{Te}$ & $<$ & 0.02 & & & \\
\hline
\end{tabular}

Preparation Information:

The standard solution is prepared using high purity materials and assayed by analytical methods for conformity prior to use. This standard was prepared using the methods developed at NIST for SRM Spectrometric Standard Solutions under appropriate laboratory conditions.

The matrix is 18 megaohm deionized water.

Stability of this product is based upon rigorous short term and long term testing of the solution for the certified value. This testing includes, but is not limited to, the effect of temperature and packaging on the product.

Intended Use:

This Certified Reference Material (CRM) is intended for use as a calibration standard for the quantitative determination of boron, calibration of instruments such as ICPOES, ICPMS, AAS and XRF, and validation of analytical methods. It also can be used in EPA, ASTM and other methods.

\author{
Lot No.: 1204016 \\ Rev. No: 5.00 \\ Page 1 of 2
}


Traceability Information:

The traceability of this standard is maintained through an unbroken chain of comparisons to appropriate standards with suitable procedure and measurement uncertainties. The maintenance of the base and derived units of International System of Units (SI) with traceability of measurement results (contemporary metrology)

to SI ensures their comparability over time as follows.

a. Standard Weight and Analytical Balance

The standard weights (NBS weights Inventory No 20231A) are calibrated every two years by South Carolina Metrology Laboratory that is a participant in "NIST Weights and Measures Measurement Assurance Program" with a certificate of measurement traceability to NIST primary standards.

The balances are calibrated yearly by the ISO 17025 accredited metrology service, and are verified weekly by an in-house method using standard weights.

b. Volumetric Device

The calibration of volumetric vessels is checked annually using the NBS 602 method.

c. Thermometer

The standard thermometers are calibrated every year by the ISO 17025 accredited metrology service. The thermometers used in-house are verified against the standard thermometers yearly.

d. Calibration Standards:

The Calibration Standard is directly traceable to SRM 3100 Series Spectrometric Standard Solutions.

Packaging and Storage Conditions:

The standard is packaged in a pre-cleaned polyethylene bottle. To maintain the integrity of this product, the solution should be kept tightly capped and stored under normal laboratory conditions.

Refer to Material Safety Datasheet (MSDS) for hazardous information.

Expiration Information:

The expiry date is guaranteed to be valid for eighteen months from the shipping date provided. For this reason, standards from the same lot may have different expiration dates.

$\begin{array}{ll}\text { Preparation Date: } & \text { February 9,2012 } \\ \text { Shipped Date: } & \text { MAR } 092012 \\ \text { Expiration Date: } & \text { SEP } 092013\end{array}$

Expiration Date:

February 29, 2012

Quality Information:

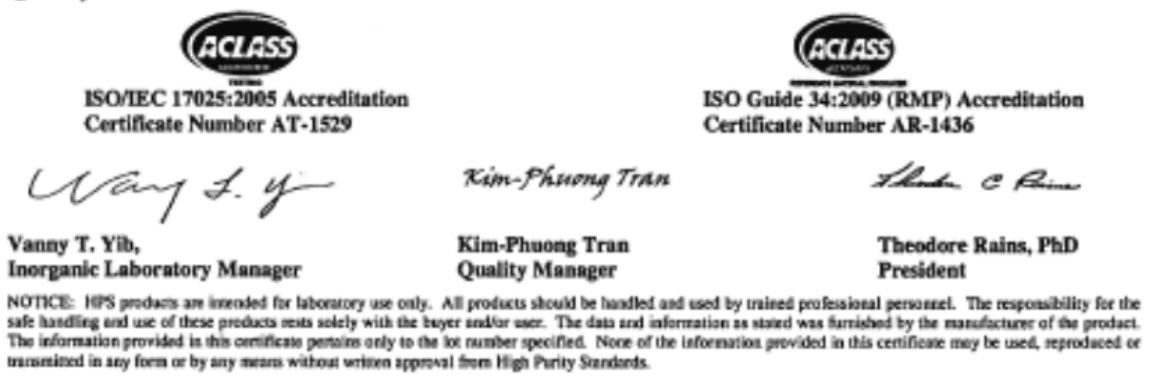

Lot No.: 1204016

Rev. No.: 5.0 .0
Page 2 of 2 